existing or projected national park or reserve, the creation of a special sanctuary, for which the high ground above the San Ramon gorge is suggested, is therefore desirable

Guemal Hippocamelus antisensis (Andean region above 4300 metres): although this deer is widespread, its total population is small. Its specialised habitat means that it lives in isolated communities and runs the risks inherent in such a situation. Hunting has eliminated it from almost all the lower parts of its former range and it is much persecuted wherever it still exists. Guemals are reported to be rather foolish animals and to be easily slaughtered once the leader of a group has been killed. The species shows none of the tenacity of Odocoileus virginianus and appears to be in delicate balance everywhere. Control of hunting is very necessary. The highest ridge of what is now the Manu National Park was formerly a wellknown haunt of this species and small numbers are thought still to exist there.

\title{
The Spectacled Bear
}

TTHE spectacled bear, the only bear in South America, is listed in the IUCN Red Book as an endangered species on the strength of the recommendation of the Seattle Conference on National Parks in 1962 that it was threatened with extinction. However, Dr Albert W. Erickson, of Minnesota, who has made a survey for the World Wildlife Fund of this bear's status in the five Latin American countries in which it occurs Venezuela, Colombia, Ecuador, Peru and Bolivia - thinks it "highly improbable that the spectacled bear is in any immediate danger of extinction', though he adds that early consideration should be given to taking steps to preserve the species. In a brief report in the WWF report for 196567, The Ark Under Way, he writes: 'In Venezuela, the northern limits of the species' range, the spectacled bear is now, and probably always has been, quite rare. This judgement is based on the fact that there are very few records of the spectacled bear from Venezuela and only one person was contacted who had even so much as observed signs of the bear on a single occasion.

'In Colombia, the spectacled bear is still to be found in portions of the west, east and central Andes mountains, although best evidence suggests that its distribution and presumed abundance in each of these ranges is markedly reduced from former times.

'The apparent status of the spectacled bear in Ecuador appears very good with near pristine populations remaining throughout the country, although agricultural activities have encroached on the bear's range along the entire valley separating the east and west ranges. However, inasmuch as the spectacled bear is infrequently found anywhere below 2000 feet, it appears unlikely that such encroachment has appreciably affected bear numbers in Ecuador.

'In Peru, as in Colombia, major reductions in the distribution of the spectacled bear are apparent. Nevertheless, the species is still found along 
the whole of the Andean range in that country, the best residual populations being found in south-eastern Peru where road systems and agricultural practices are less developed [see Major Grimwood's report, page 415].

'Though the status of the spectacled bear in Bolivia was less adequately assessed than in the other four countries, it appears to be quite good, though to a lesser degree than in Ecuador.

'On the whole, the results of this survey support the view that the spectacled bear has suffered major reductions in its distribution and numbers from times past. The apparent causes for the diminished status of the species are the spread of agriculture and the development of roads, coupled with the lack of effective conservation practices. The species is also quite heavily hunted for sport, and controlled on livestock ranges and in other agricultural areas. This sequence of events can be expected to continue as these countries undergo further development. This does not imply that the spectacled bear is threatened with extinction. Rather, several considerations bode well for its preservation. Chief among these considerations is the fact that the species enjoys a wide distribution extending across five national boundaries and many political units, and has adapted itself to a broad spectrum of diverse habitats, ranging from near-desert cactus and other plant associations at $\mathbf{1 5 0 0}$ foot elevation, through dry-deciduous, rain and cloud forests to treeless alpine-like associations exceeding 12,000 feet in elevation. The spectacled bear has also shown a remarkable ability to withstand heavy hunting pressures and to persist in isolated pockets of habitat.'

Dr Erickson suggests two steps that should be taken immediately: that WWF and the conservation organisations should look at the larger problem of preserving major areas of Andean habitat in nature reserves, etc, and that they should foster conservation legislation for the management and preservation of South American wildlife. If something effective could be achieved in these directions, it would assure the preservation of the spectacled bear - and many other species as well.

\section{Brazil's Endangered Mammals}

A LIST of animals and plants in danger of extinction in Brazil, compiled by A Professor Carvalho, who is president of the Foundation, FPS correspondent in Brazil, and a member of the IUCN board, is published in the 1968 Boletim Informativo of the Brazilian Foundation for the Conservation of Nature. The 19 mammals listed include eight monkeys - woolly spider Brachyteles arachnoides, bald and black-headed uakaris, Cacajao calvus and $C$. melanocephalus, whitenosed saki Chiropotes albinasus, Goeldi's tamarin Callimico goeldii, golden lion marmoset Leontideus rosalia, and golden-headed and golden-rumped tamarins $L$. chrysomelas and $L$. chrysopygus - maned wolf Chrysocyon brachyurus, giant and American otters, Pteronura brasiliensis and Lutra platensis, bush dog Speothus venaticus, small-eared fox Atelocynus microtis, giant armadillo Priodontes giganteus, giant anteater Myrmecophaga tridactyla, three-toed sloth Bradypus torquatus, manatee Trichechus inunguis, and marsh and pampas deer Blastocerus dichotomus and Ozotocerus bezoarticus. 